\title{
ANALISIS MARJIN PEMASARAN AGROINDUSTRI BERAS DI KOTA MATARAM
}

\section{MARKETING MARGIN ANALYSIS OF RICE AGROINDUSTRY IN MATARAM CITY}

\author{
Wuryantoro dan Candra Ayu \\ Program Studi Agribisnis Fakultas Pertanian Unram \\ Korespondensi: wuryantorow@yahoo.com
}

\begin{abstract}
ABSTRAK
Kota Mataram sebagai ibukota provinsi sekaligus pusat ekonomi, budaya dan jasa memiliki tingkat konsumsi akan bahan pangan terutama beras sangat tinggi. Hal ini karena kepadatan penduduk di Kota Mataram yang tinggi. Di Kota Mataram, aliran produksi beras mulai dari produsen hingga sampai ke konsumen membentuk saluran pemasaran. Dengan membuat pemetaan saluran beras yang terdapat di Kota Mataram dapat diketahui hubungan antara masing-masing lembaga pemasaran yang terlibat dan margin pemasaran yang tercipta. Tujuan dari penelitian ini adalah menganalisis margin dan efisiensi pemasaran yang diperoleh oleh setiap lembaga pemasaran dalam agroindustri beras di Kota Mataram. Metode yang digunakan dalam penelitian ini adalah metode deskriptif, sedangkan pengumpulan data dengan teknik survei dengan mewawancarai responden yang terdiri petani (pedagang gabah), pedagang di tingkat penggilingan (Rice Milling Unit), pedagang besar, dan pedagang pengecer. Hasil penelitian menunjukkan bahwa margin dan keuntungan pemasaran yang terbesar dari proses distribusi beras, terdapat pada pedagang di tingkat penggilingan, sedangkan yang terkecil terdapat pada pedagang pengecer, serta proses jalur distribusi atau saluran pemasaran beras di Kota Maram telah efisien.
\end{abstract}

Kata kunci: Saluran Pemasaran, Margin, Efisiensi

\begin{abstract}
Mataram City as the provincial capital as well as the center of economy, culture and services has a very high level of consumption of food, especially rice. This is due to the high population density in Mataram City. In Mataram City, the flow of rice production from producers to consumers forms a marketing channel. By mapping the rice channels in the city of Mataram, the relationship between each marketing agency involved and the marketing margins created can be seen. The purpose of this study was to analyze the marketing margins and efficiency obtained by each marketing agency in the rice agro-industry in Mataram City. The method used in this research is descriptive method, while data collection is by survey technique by interviewing respondents consisting of farmers (grain traders), traders at the rice milling level
\end{abstract}


(Rice Milling Unit), wholesalers, and retailers. The results showed that the largest marketing margins and profits from the rice distribution process were found at traders at the milling level, while the smallest was found in retailers, as well as the distribution channel process or rice marketing channels in Maram City which was efficient.

Key Words: Marketing Chanel, Margin, Efficiency

\section{PENDAHULUAN}

Padi merupakan bahan pangan pokok bagi penduduk Indonesia yang memberikan energi dan zat gizi yang tinggi. Padi telah menjadi komoditas strategis dalam kehidupan bernegara di Indonesia. Peran padi, selain sebagai sumber pangan pokok juga menjadi sumber penghasilan bagi petani dan kebutuhan hidup sehari-hari bagi jutaan penduduk. Padi juga bisa dijadikan sebagai komoditas politik, karena keberadaannya tidak dapat digantikan oleh komoditas lain dan harus dalam jumlah yang memadai. Meskipun pemerintah telah mengupayakan diversifikasi pangan, namun sampai saat ini belum mampu mengubah preferensi penduduk terhadap bahan pangan padi atau beras (Sabarella, et al. 2019).

Beras menjadi komoditas pangan yang paling pokok bagi sebagian besar masyarakat Indonesia. Bahkan, beras merupakan food habit sehingga masyarakat beranggapan bahwa belum dikatakan makan kalau belum makan nasi. Peran beras menjadi salah satu jenis pangan pokok di Indonesia sampai saat ini sulit disubstitusikan dengan jenis makanan pokok yang lain. Ketergantungan dalam hal pangan ini dikarenakan pangan pokok mayoritas penduduk Indonesia yaitu beras seringkali mengalami fluktuasi. Fluktuasi ini dipengaruhi produktivitas padi petani. Produktivitas padi dipengaruhi oleh banyak aspek antara lain cuaca dan iklim, hama penyakit maupun teknologi budidaya yang diterapkan petani. Sehingga stok gabah/beras seringkali tidak tersedia cukup (deficit supply) yang memicu kenaikan harga (Cakra, 2016)

Petani merupakan produsen utama dalam pengelolaan beras. Dengan kerja yang maksimal petani dapat membantu menstabilkan perekonomian Indonesia tentu dengan berperan aktif dalam pertanian maupun ketahanan pangan. Namun yang menjadi permasalahannya saat ini kesejahteraan petani di Indonesia masih rendah. Rendahnya kesejahteraan petani ini dikarenakan rendahnya nilai tambah produk yang dinikmati oleh petani. Petani menjual produk pertanian hasil panen begitu saja. Banyak petani menjual hasil pertanian, misalnya padi, ketika masih berada di sawah (Sihombing, dan Sumarauw, 2015).

Dalam sistem pemasaran, masalah utama yang sering muncul ke permukaan ialah bahwa harga gabah yang diterima petani hampir selalu rendah pada musim panen. Sebaliknya, konsumen di perkotaan sering mengeluhkan tingginya harga beras. Kondisi tersebut mencerminkan bahwa pasar beras tidak simetris dan kurang terintegrasi. Artinya, jika harga beras di tingkat konsumen naik, kenaikan tersebut tidak tertransmisi ke tingkat petani. Namun jika harga beras di kota turun, penurunan tersebut akan segera menyebabkan turunnya harga gabah di tingkat petani. Petani 
selalu berada pada posisi yang tidak diuntungkan oleh mekanisme pasar. Sebaliknya, jika harga gabah di tingkat petani naik, maka harga beras yang dibayar konsumen dapat dipastikan naik. Namun jika harga gabah di tingkat petani turun maka penurunan tersebut belum tentu menyebabkan turunnya harga beras di tingkat konsumen. Dalam hal ini konsumen dirugikan. Sifat pasar gabah/beras yang tidak simetri ini akan menjadi ladang keuntungan bagi pedagang. Sementara itu baik produsen (petani) maupun konsumen sama-sama dirugikan. Rendahnya tingkat transmisi harga, mencerminkan rendahnya efisiensi pasar (Swastika dan Sumaryanto, 2015)

Marjin pemasaran merupakan perbedaan antara harga yang dibayarkan oleh konsumen dengan harga yang diterima petani atau merupakan biaya dari jasa-jasa pemasaran yang dibutuhkan sebagai akibat dari permintaan dan jasa-jasa pemasaran. Semakin besar perbedaan harga antara lembaga-lembaga tataniaga yang terlibat, terutama antara harga yang terjadi di tingkat eceran dengan harga yang diterima petani, maka semakin besar pula marjin tataniaga dari komoditi yang bersangkutan, dan semakin tidak efisien pemasarannya.

Kota Mataram sebagai ibukota provinsi sekaligus pusat ekonomi, budaya dan jasa memiliki tingkat konsumsi akan bahan pangan sangat tinggi. Hal ini karena kepadatan penduduk di Kota Mataram yang tinggi. Di Kota Mataram, aliran produksi hingga sampai ke konsumen membentuk saluran pemasaran. Dengan membuat pemetaan saluran beras yang terdapat di Kota Mataram dapat diketahui hubungan antara masing-masing lembaga pemasaran yang terlibat dan margin pemasaran yang tercipta. Tujuan dari penelitian ini adalah menganalisis margin dan efisiensi pemasaran yang diperoleh oleh setiap lembaga pemasaran dalam agroindustri beras di Kota Mataram

\section{METODOLOGI PENELITIAN}

\section{Metode dan Teknik Penelitian}

Metode penelitian merupakan cara ilmiah untuk mendapatkan data, baik data yang bersifat primer maupun sekunder untuk tujuan dan kegunaan tertentu .Metode dasar yang digunakan dalam penelitian ini adalah metode deskriptif, yaitu memusatkan diri pada pemecahan masalah-masalah yang ada pada masa sekarang dan pada masalah yang aktual. Metode ini digunakan dengan cara mengumpulkan data, menyusun, menganalisa, menginterpretasikannya dan akhirnya menarik kesimpulan. . Pengumpulan data dilakukan dengan teknik survei yaitu dengan mengadakan wawancara mendalam (in-depth interview) dengan responden (Nazir, 2014).

\section{Penetapan Lokasi dan Sampel Penelitian}

Penelitian dilakukan di empat kelurahan yang terdapat di Kota Mataram yaitu Kelurahan Jempong Baru di Kecamatan Sekarbela, Kelurahan Pejarakan Karya di Kecamatan Ampenan, Kelurahan Sayang-sayang di Kecamatan Cakranegara, dan Kelurahan Bertais di Kecamatan Sandubaya secara purposive sampling atas pertimbangan bahwa kelurahan tersebut memiliki unit usaha penggilingan padi berkelanjutan. 
Data yang digunakan adalah data primer dengan melakukan wawancara dan data sekunder diperoleh dari instansi-instansi yang terkait. Sampel dari penelitian ini adalah 1 pedagang pengumpul gabah, 4 Rice Milling Unit (RMU atau Penggilingan Padi) dimana masing-masing kelurahan di tetapkan $1 \mathrm{RMU}$, dan pedagang beras yang ditentukan dengan teknik snowball sampling dimana RMU menjadi titik awal (starting point).

\section{Analisis Data}

Data yang terkumpul dianalisis secara kualitatif dan kuantitatif, dengan menggunakan analisis sebagai berikut:

1. Untuk mengetahui saluran pemasaran dianalisis secara deskriptif

2. Untuk mengetahui margin pemasaran agroindustri beras, menggunakan formulasi sebagai berikut :

a. Margin pemasaran beras dapat diketahui dengan rumus (Rahim dan Hastuti, 2007) :

$$
\mathrm{MPb}=\mathrm{Prb}-\mathrm{Pfb}
$$

Keterangan :

$\mathrm{MPb}=$ margin pemasaran beras (rupiah/kilogram)

$\operatorname{Prb}=$ harga beras tingkat konsumen beras (rupiah/kilogram)

$\mathrm{Pfb}=$ harga beras ditingkat pedagang penggilingan (rupiah/ kilogram)

Penarikan kesimpulan yaitu semakin kecil marjin pemasaran beras, maka semakin efisien suatu pemasaran. Atau kriteria pengambilan keputusan dapat dilakukan dengan cara sebagai berikut:

- Jika Pfb > MPb , maka pemasaran beras adalah efisien.

- Jika Pfb $<$ MPb, maka pemasaran beras adalah tidak efisien

b. Indeks efisiensi pemasaran adalah merupakan perbandingan antara total biaya dengan total nilai produk yang dipasarkan. Menurut Soekartawi (2002) indeks dapat dihitung dengan menggunakan rumus sebagai berikut:

Keterangan:

$$
\mathrm{Ep}=\mathrm{BP} / \mathrm{TNP} \times 100 \%
$$

Ep $=$ Efisiensi pemasaran $(\%)$

$\mathrm{Bp}=$ Biaya pemasaran $(\mathrm{Rp} / \mathrm{kg})$

$\mathrm{TNP}=$ Total Nilai Produksi beras $(\mathrm{Rp} / \mathrm{Kg})$

Kriteria penarikan kesimpulan yakni semakin kecil indeks efisiensi pemasaran maka semakin efisien saluran pemasaran tersebut

c. Share produsen adalah bagian harga yang diterima produsen terhadap harga yang dibayar oleh konsumen dengan menggunakan rumus (Downey dan Erickson,1992):

$$
\mathrm{SP}=\frac{\mathrm{PF}}{\mathrm{PR}} \times 100 \%
$$

$\mathrm{SP}=$ Share Produsen

$\mathrm{PF}=$ Harga di tingkat Produsen

PR = Harga Beli di tingkat Konsumen

Kriteria Keputusan Share Produsen :

Pemasaran dikatakan efisien jika perbandingan bagian harga yang diterima petani produsen produsen lebih dari $60 \%$ dari harga ditingkat konsumen, sedangkan jika harga jual produsen kurang dari $60 \%$ dari harga ditingkat konsumen maka pemasaran beras belum dikatakan efisien. 


\section{HASIL PENELITIAN DAN PEMBAHASAN}

\section{Analisis Saluran Pemasaran Beras}

Saluran pemasaran adalah suatu jalur atau hubungan yang dilewati, oleh arus barang/jasa dari produsen sampai kepada konsumen yang melibatkan beberapa organisasi atau lembaga pemasaran. Saluran pemasaran produk pertanian bisa merupakan jalur panjang yang amat rumit atau suatu jalur yang sederhana. Hasil penelitian saluran pemasaran di Kota Mataram dapat dilihat pada bagan berikut:

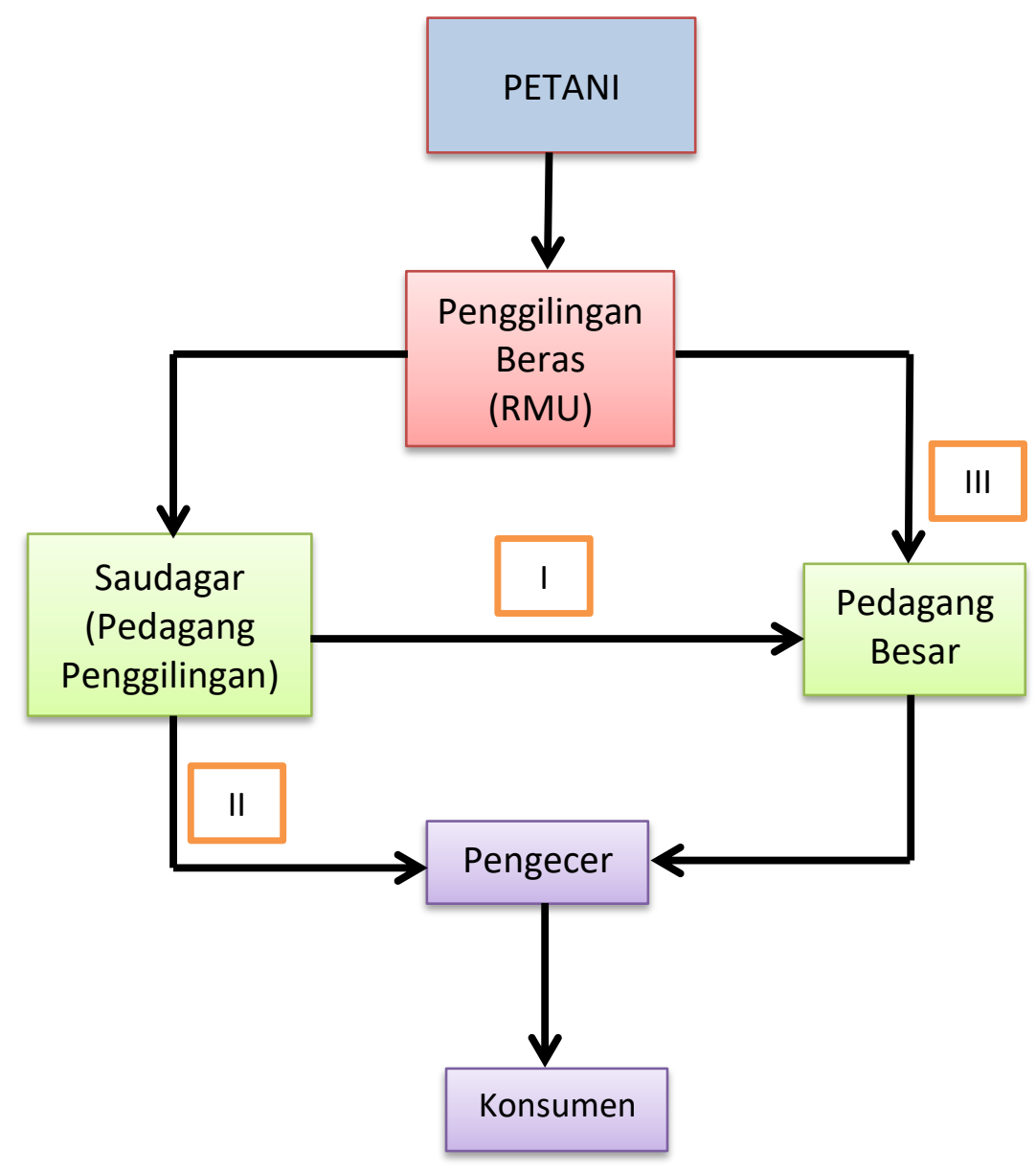

Bagan Saluran Distribusi Beras

Pada bagan 4 di atas dapat dilihat bahwa saluran pemasaran yang terjadi di Kota Mataram mulai dari petani hingga konsumen akhir sangat sederhana, yakni hanya melibatkan 3 atau 4 lembaga pemasaran saja. Hasil penelitian menunjukkan terdapat 3 pola saluran pemasaran beras di Kota Mataram, yakni:

1. Saluran pemasaran pola I yaitu jalur distribusi beras yang melibatkan 4 lembaga pemasaran, dimulai dari petani menuju saudagar (pedagang di tingkat penggilingan) lalu ke pedagang besar selanjutkan ke pedagang pengecer kemudian ke konsumen akhir. 
2. Saluran pemasaran pola II melibatkan tiga lembaga pemasaran yakni petani ke saudagar lalu saudagar memasarkan beras pedagang pengecer selanjutnya ke konsumen akhir.

3. Saluran pemasaran pola III melibatkan tiga lembaga pemasaran yakni petani ke pedagang besar lalu pedagang besar memasarkan beras pedagang pengecer selanjutnya ke konsumen akhir.

Dari gambaran di atas diketahui bahwa pola distribusi atau pemasaran beras di Kota Mataram dari pedagang pengumpul gabah sampai ke konsumen akhir cukup sederhana yakni hanya melibatkan paling banyak melibatkan 4 lembaga pemasaran yakni pedagang pengumpul gabah, pedagang di tingkat penggilingan (saudagar), pedagang besar dan konsumen akhir. Saluran pemasaran dimulai dari pedagang pengumpul gabah kemudian melakukan penjualan di tempat penggilingan untuk bertransaksi dengan pedagang di tingkat penggilingan atau saudagar dan atau ke pedagang besar lalu kedua pedagang beras tersebut memasarkan ke konsumen akhir. Perbedaaan antara pedagang beras di tingkat penggilingan yang dalam hal ini dikenal sebagai saudagar dengan pedagang besar adalah terletak dalam cara memasarkan beras. Saudagar memasarkan beras menggunakan kemasan karung, sedangkan pedagang besar memasarkan beras dengan menggunakan kemasan plastik yang diberi merek. Perbedaan selanjutnya adalah saudagar memasarkan beras di pasar tradisional, sedangkan pedagang besar memasarkan sebagian besar berasnya ke toko atau kios yang relatif besar

\section{Analisis Margin dan Efisiensi Pemasaran Beras}

Pemasaran merupakan kegiatan penyampaian barang dari tingkat produsen ke tingkat konsumen dengan usaha untuk memperoleh barang yang diperlukan. Pemasaran komoditi pertanian, khususnya gabah atau beras tidak begitu saja disampaikan dari petani ke konsumen, namun terdapat proses yang panjang serta membutuhkan perlakuan-perlakuan yang khusus dibandingkan produk non pertanian.

Dari gambaran saluran pemasaran di atas diketahui bahwa pada umumnya pelaku atau lembaga pasaran yang terlibat dalam distribusi beras di Kota Mataram adalah: Petani $\rightarrow$ Pedagang beras di tingkat penggilingan $\rightarrow$ Pedagang Besar $\rightarrow$ Pedagang Pengecer $\rightarrow$ Konsumen.

Berikut adalah hasil analisis margin pemasaran dan sekaligus efisiensi pemasaran beras yang terdapat di Kota Mataram.

Suatu sistem pemasaran dapat dikatakan efisien yaitu mampu mengadakan pembagian yang adil dari keseluruhan harga yang dibayarkan konsumen akhir. Dalam penelitian analisis margin dan efisiensi pemasaran ditujukan pada saluran distribusi beras yang terpanjang yakni pada pada pola I yakni saluran pemasaran yang melibatkan 4 lembaga pemasaran: petani, saudagar pedagang besar dan pedagang pengecer. Hasil analisis terhadap margin dan efisiensi pemasaran beras di Kota Mataram disajikan dalam tabel berikut. 
Tabel 1. Analisis Margin dan Efisiensi Pemasaran Beras di Kota Mataram Tahun 2020

\begin{tabular}{|c|c|c|}
\hline No. & URA I A N & Ni l a i \\
\hline 1. & $\begin{array}{l}\text { Petani } \\
\text { Harga jual GKG }(\mathrm{Rp} / \mathrm{Kg})\end{array}$ & 4900 \\
\hline \multirow[t]{5}{*}{2.} & Saudagar (Pedagang Penggilingan) & \\
\hline & Harga beli & 4900 \\
\hline & Harga jual beras (Rp/Kg) & 9200 \\
\hline & $\begin{array}{l}\text { Biaya Pemasaran } \\
\text { - Biaya Sewa mesin (Huller) }(\mathrm{Rp} / \mathrm{Kg}) \\
\text { - Biaya Tenaga Kerja } \\
\text { - Biaya Kemasan } \\
\text { - Biaya Transportasi }\end{array}$ & $\begin{array}{r}450 \\
175 \\
25 \\
150\end{array}$ \\
\hline & $\begin{array}{l}\text { Margin } \\
\text { Keuntungan }\end{array}$ & $\begin{array}{l}4300 \\
3550\end{array}$ \\
\hline \multirow[t]{5}{*}{3.} & Pedagang Besar & \\
\hline & Harga beli & 9200 \\
\hline & Harga jual & 10700 \\
\hline & $\begin{array}{l}\text { Biaya Pemasaran }(\mathrm{Rp} / \mathrm{Kg}) \\
\text { - } \quad \text { Biaya Tenaga Kerja }(\mathrm{Rp} / \mathrm{Kg}) \\
\text { - }\end{array}$ & $\begin{array}{r}75 \\
125 \\
150\end{array}$ \\
\hline & $\begin{array}{l}\text { Margin } \\
\text { Keuntungan }\end{array}$ & $\begin{array}{l}1500 \\
1150\end{array}$ \\
\hline \multirow[t]{6}{*}{4.} & Pedagang Pengecer & \\
\hline & Harga Beli & 10700 \\
\hline & Harga jual & 11500 \\
\hline & $\begin{array}{l}\text { Biaya Pemasaran } \\
\text { - } \quad \text { Biaya Tenaga Kerja }(\mathrm{Rp} / \mathrm{Kg}) \\
\text { - } \quad \text { Biaya Lain2 }\end{array}$ & $\begin{array}{l}75 \\
50\end{array}$ \\
\hline & Margin & 800 \\
\hline & Keuntungan & 675 \\
\hline 5. & $\begin{array}{l}\text { Analisis Efisiensi Pemasaran: } \\
\text { (Total Biaya Pemasaran) } \\
\text { 1. Margin Pemasaran Keseluruhan } \\
\text { 2. Indek Ef. Pemasaran }(\%) \\
\text { 3. Share Harga }(\%)\end{array}$ & $\begin{array}{r}1025 \\
2300 \\
9 \\
80\end{array}$ \\
\hline
\end{tabular}

\section{Analisis Margin Pada Setiap Lembaga Pemasaran}

\section{Pedagang Beras di Tingkat Penggilingan}

Dari tabel diatas diketahui bahwa aktivitas distribusi beras dimulai dari Rice Milling Unit atau penggilingan padi. Penggilingan padi memiliki peran yang sangat penting dalam sistem rantai pasok padi/beras di Indonesia. Penggilingan padi 
merupakan pusat pertemuan antara produksi, pasca panen, pengolahan dan pemasaran gabah/beras sehingga merupakan mata rantai penting dalam rantai pasok beras nasional. Penggilingan memberikan kontribusi dalam penyediaan beras, baik dari segi kuantitas maupun kualitas untuk mendukung ketahanan pangan nasional.

Berdasarkan Tabel 1, analisis margin dan efisiensi pemasaran dapat diketahui bahwa pedagang penggiling atau dalam penelitian ini sering disebut sebagai saudagar membeli gabah dari petani atau petani yang berperan sebagai pedagang pengumpul gabah dengan harga $\mathrm{Rp} 4$ 900/Kg dalam bentuk gabah kering giling. Namun sebelum menggiling saudagar biasanya menjemur gabah lagi selama satu hari untuk mendapatkan hasil beras yang baik. Selanjutnya pedagang penggiling mengolah gabah menjadi beras dan menjual beras ke pedagang besar atau langsung ke pengecer dengan harga Rp 9200/kg. Besarnya margin yang diperoleh pedang penggiling karena terjadinya proses perubahan dari gabah menjadi beras $\mathrm{Rp} 4300 / \mathrm{Kg}$. Dengan biaya pemasaran yang dikeluarkan pedagang penggiling sebesar $\mathrm{Rp} 650 / \mathrm{Kg}$, keuntungan yang diperoleh Rp 3 550/Kg.

\section{Pedagang Besar}

Pedagang besar yang dimaksud dalam penelitian ini adalah pedagang yang membeli beras dari pedagang penggiling atau yang melakukan penggilingan gabah sendiri yang selanjutnya dilakukan pembersihan dan pengemasan dalam plastik $10 \mathrm{~kg}$ atau $5 \mathrm{~kg}$ yang diberi merek. Hasil penelitian menunjukkan bahwa volume pembelian pedagang besar dari pedagang penggiling lebih besar daripada dia melakukan penggilingan sendiri. Hal ini disebabkan karena pembelian beras dari pedagang penggilingan mempunyai risiko lebih kecil, serta dapat mengetahui kualitas beras yang dibelinya.

Hasil analisis margin pada Tabel 1, menunjukkan bahwa pedagang besar membeli beras dengan harga Rp 9 200/kg. Selanjutnya pedagang besar menjual beras ke pedagang pengecer dengan harga $\mathrm{Rp} 10700 / \mathrm{kg}$ dan margin pemasaran yang dihasilkan sebesar Rp 1 500/kg. Biaya pemasaran yang dikeluarkan yang dikeluarkan oleh pedagang besar adalah sebesar Rp 350/kg dengan keuntungan yang diperolehnya sebesar Rp 1 150/kg.

\section{Pedagang Pengecer}

Pedagang pengecer adalah pedagang yang menjual beras kepada konsumen akhir, yakni konsumen yang membeli beras untuk dikonsumsi sendiri. Tabel 1 analisis margin di atas menunjukkan bahwa harga pembelian beras oleh pedagang pengecer Rp 10 700/kg dan menjualnya dengan harga Rp 11 500/kg, sehingga menghasilkan margin sebesar Rp 800/kg dengan keuntungan Rp 674/kg seta biaya pemasaran yang dikeluarkan sebesar Rp 125/kg.

Berdasarkan pemaparan di atas maka dapat diketahui bahwa margin dan keuntungan pemasaran tidak tersebar secara merata. Hasil analisis Tabel 1 menunjukkan bahwa pedagang beras di tingkat penggilingan menikmati margin dan keuntungan yang terbesar dari proses distribusi beras di Kota Mataram. Hal ini dapat dipahami karena aktifitas yang dilakukan oleh pedagan penggilingan begitu banyak dan mempunyai risiko yang paling besar dibandingkan dengan pedagang besar dan pedagang pengecer. Seperti sudah dijelaskan sebelumnya bahwa proses distribusi beras dimulai dari RMU yakni dari pedagang penggilingan, dimana pedagang 
penggilingan melakukan pembelian gabah dan penjemuran serta memproses gabah menjadi beras, dengan risiko kualitas beras yang tidak bagus serta rendemen yang dihasilkan kecil pula. Sementara itu di tingkat pedagang pengecer margin dan keuntungan yang dihasilkan paling kecil, hal ini juga dapat dipahami bahwa pedagang pengecer hampir tidak mempunyai risiko dalam proses distribusi beras ke konsumen akhir. Pedagang pengecer hanya berperan dalam penyediaan tempat penjualan, sedangkan biaya transportasi ditanggung oleh pedagang besar dengan sistem pembayaran tunda.

\section{Analisis Efisiensi Pemasaran}

Pemasaran merupakan kegiatan penyampaian barang dari tingkat produsen ke tingkat konsumen dengan usaha untuk memperoleh barang yang diperlukan. Suatu sistem pemasaran dapat dikatakan efisien yaitu mampu mengadakan pembagian yang adil dari keseluruhan harga yang dibayarkan konsumen akhir. Puspitawati dan Wardhani (2013) untuk mengetahui efisiensi beras dilakukan dengan analisis margin pemasaran dan indek efisiensi pemasaran dan share produsen.

Berdasarkan tabel di atas diketahui bahwa jalur distribusi yang dilalui beras menunjukkan saluran pemasaran yang efisien. Hal tersebut ditunjukkan oleh hasil nilai perhitungan pengukuran efisiensi pemasaran baik hasil analisis margin, indeks efisiensi maupun share harga, telah memenuhi kriteria efisien.

Hasil analisis efisiensi pemasaran dengan pendekatan margin pemasaran, menunjukkan bahwa total nilai margin pemasaran yang dihasilkan adalah sebesar $\mathrm{Rp}$ $2300 / \mathrm{kg}$. Menurut Rahim dan Hastuti, (2007) sepanjang nilai jual beras per kilogramnya lebih besar dari nilai margin pemasaran maka saluran pemasaran tersebut dikategorikan efisien. Dari tabel di atas diketahui bahwa nilai jual atau harga beras di tingkat konsumen akhir adalah Rp $11500 / \mathrm{kg}$. Dengan demikian dapat dikatakan bahwa saluran pemasaran yang ada di Kota Mataram telah efisien. Selanjutnya hasil perhitungan dengan indeks efisiensi menunjukkan bahwa ketiga saluran pemasaran yang terdapat di daerah penelitian juga telah efisien. Menurut Soekartawi (2002) jika nilai indeks efisiensi pemasaran kurang dari $100 \%$ maka saluran pemasaran komoditi tersebut telah efisien dan semakin kecil indeks pemasaran yang dihasilkan oleh maka semakin efisien pemasaran tersebut. Hasil analisis menunjukkan bahwa nilai indeks saluran pemasaran di Kota Mataram adalah sebesar $9 \%$. Indeks efisiensi pemasaran adalah merupakan perbandingan antara total biaya dengan total nilai produk yang dipasarkan. Melihat kecilnya nilai persentase tersebut maka dikatakan biaya pemasaran yang diperlukan untuk melakukan distribusi beras dari produsen dan konsumen sangat kecil dibandingkan dengan harga berasnya.

Perhitungan efisiensi dengan menggunakan pendekatan share harga juga menghasilkan keputusan bahwa saluran pemasaran beras di Kota Mataram telah efisien. Share harga menunjukkan perbandingan harga ditingkat produsen dengan harga di tingkat konsumen. Menurut Downey dan Erickson (1992) , jika perbandingan bagian harga yang diterima petani produsen produsen lebih dari $60 \%$ dari harga ditingkat konsumen maka saluran pemasaran tersebut efisien. Hasil analisis share harga produsen menunjukkan bahwa saluran pemasaran di Kota Mataram menghasilkan nilai $80 \%$ dan lebih besar dari $60 \%$, yang bermakna pula. produsen beras menikmati bagian harga yang paling besar dibandingkan pelaku pemasaran lainnya. 


\section{KESIMPULAN DAN SARAN}

\section{Kesimpulan}

1. Margin dan keuntungan pemasaran yang terbesar dari proses distribusi beras, terdapat pada pedagang di tingkat penggilingan, sedangkan yang terkecil terdapat pada pedagang pengecer.

2. Hasil analisis efisiensi dengan menggunakan indikator margin pemasaran, indeks efisiensi dan share harga menunjukkan bahwa proses distribusi beras di Kota Mataram menghasilkan saluran pemasaran yang efisien

\section{Saran}

Margin dan keuntungan pemasaran tidak tersebar merata antara satu pelaku pemasaran dengan pelaku pemasaran yang lain, untuk itu pedagang besar dan lebih-lebih pedagang pengecer perlu melakukan pengurangan biaya pemasaran serta meningkatkan volume penjualan serta jika diperlukan meningkatkan harga jual berasnya.

\section{DAFTAR REFERENSI}

Cakra, I Putu, et al. 2016. Perilaku Petani pada Hasil Panen Gabah di Nusa Tenggara Barat. Balai Pengkajian Teknologi Pertanian NTB.

Downey, W.D. dan S.P. Erickson. 1992. Manajemen Agribisnis. Erlangga. Jakarta.

Nazir Moh. 2014 Metode Penelitian. Ghaila Indonesia 2014

Porter, M. 1985. Value chain Framework. http://www.12manage.com/methods porter value chain.html. (diakses taganggal 11 Januari 2018).

Puspitawati dan Wardhani. 2013. Analisa Efisiensi Pemasaran Komoditi Cabai (Capsicum Annum L) pada Beberapa Saluran Pemasaran Di Kota Madiun. Jurnal Agri-tek. 14 (1)

Rahim, Abd dan Hastuti, Diah Retno D. 2007. Pengantar, Teori dan Kasus Ekonomika Pertanian. Jakarta : Penebar Swadaya

Sabarella, et al. 2019. Buletin Konsumsi Pangan. Kementerian Pertanian. Jakarta.

Salsabilla. S. M., 2014. Analisis Manajemen Rantai Pasok (Supply Chain Manajemen) Padi Pasca Panen di Pabrik Beras Sukoreno Makmur Kecamatan Kalisat (jurnal). Universitas Jember. Diakses tanggal 15 September 2016.

Sihombing, DT., dan Sumarauw, J., 2015. Analisis Nilai Tambah Rantai Pasokan Beras Di Desa Tatengesan Kecamatan Pusomaen Kabupaten Minahasa Tenggara. Jurnal EMBA. Vol.3 No.2 Th. 2015, Hal. 798-805. Universitas Sam Ratulangi Manado

Soekartawi. 2002. Prinsip- Prinsip Dasar Ekonomi Pertanian Teori dan Aplikasi Edisi Revisi. Raja Grafindo Persada: Jakarta

Swastika, D.K.S. dan Sumaryanto, 2015. Rantai Pasok Beras Di Indonesia (Kasus Provinsi Jabar, Kalbar, Dan Kalsel. Pusat Sosial Ekonomi dan Kebijakan Pertanian Jl. A. Yani No.70 Bogor. 